\title{
PENGGUNAAN MEDIA PEMBELAJARAN BERBASIS AUDIO VISUAL UNTUK MENINGKATKAN HASIL BELAJAR BAHASA INDONESIA DI SEKOLAH DASAR
}

\author{
Toto Sumianto $^{1}$, Sigit Vebrianto Susilo ${ }^{2}$, Bella Febriani ${ }^{3}$ \\ ${ }^{1,2,3}$ Program Studi PGSD FKIP Universitas Majalengka \\ totosumianto@yahoo.com
}

\begin{abstract}
Use of instructional media becomes a necessity for teachers in running the learning wheel. The presence of learning media is very important because it can help teachers describe the concepts of learning in the real classroom. Indonesian Language Learning in Elementary Schools has a very important role in the development of language skills in reading, writing, listening, and speaking. This study uses a quasi-experimental research method with a location in Leuwikidang 1 Primary School, Kasokandel District, Majalengka Regency. The research subjects were students in grade $V$ of Leuwikidang 1 Elementary School, as many as 40 students consisting of 20 students for class $A$ as the control class and 20 students for class $B$ as the experimental class. The results showed that the effectiveness of audiovisual learning media on Indonesian language learning could improve results better than learning without using audio visual media. This is indicated by the acquisition of scores on the test of learning outcomes (posttest) is superior to (pretest). The results of the pretest from the experimental class that is obtained an average of 45.25 and for the control class of 41.25. For the posttest results of the experimental class that is obtained an average of 70.25 and for the control class of 53.65. In conclusion, the effectiveness of audiovisual learning media in increasing student learning outcomes in Indonesian language learning in fifth grade elementary school students can significantly distinguish student learning outcomes.

Keywords: Audio Visual Learning Media; Indonesian Language Learning in Elementary School.
\end{abstract}

\begin{abstract}
Abstrak
Penggunaan media pembelajaran menjadi suatu keniscayaan bagi guru dalam menjalankan roda pembelajaran. Kehadiran media pembelajaran menjadi sangat penting karena dapat membantu guru menguraikan konsep pembelajaran secara nyata di dalam kelas. Pembelajaran Bahasa Indonesia di Sekolah Dasar memiliki peranan yang sangat penting bagi pengembangan keterampilan berbahasa baik membaca, menulis, menyimak, dan berbicara. Penelitian ini menggunakan metode penelitian Quasi eksperimen dengan lokasi di Sekolah Dasar Negeri Leuwikidang 1 Kecamatan Kasokandel Kabupaten Majalengka. Subjek penelitian adalah siswa kelas V SD Negeri Leuwikidang 1, sebanyak 40 siswa yang terdiri dari 20 siswa untuk kelas A sebagai kelas kontrol dan 20 siswa untuk kelas B sebagai kelas eksperimen. Hasil penelitian menunjukan bahwa efektivitas media pembelajaran audio visual pada pembelajaran Bahasa Indonesia dapat meningkatkan hasil yang lebih baik disbanding dengan pembelajaran yang tanpa menggunkan media audio visual. Hal ini ditunjukan dengan perolehan skor pada tes hasil belajar (posttest) lebih unggul dari (pretest). Adapun hasil pretest dari kelas eksperimen yaitu memperoleh rata-rata sebesar 45,25 dan untuk kelas kontrol sebesar 41,25. Untuk hasil posttest dari kelas eksperimen yaitu memperoleh ratarata sebesar 70,25 dan untuk kelas control sebesar 53,65. Kesimpulan, efektivitas media pembelajaran audio visual dalam meningkatakan hasil belajar siswa pada pembelajaran Bahasa Indonesia pada siswa kelas V Sekolah Dasar dapat membedakan hasil belajar siswa secara signifikan.
\end{abstract}

Kata Kunci: Media Pembelajaran Audio Visual; Pembelajaran Bahasa Indonesia di SD

\begin{tabular}{llll}
\hline Received & $: 2020-04-23$ & Approved & $: 2020-05-29$ \\
Reviesed & $: 2020-05-08$ & Published & $: 2020-07-31$ \\
\hline
\end{tabular}

cc) (†) (? Jurnal Cakrawala Pendas is licensed under a Creative Commons Attribution-

ShareAlike 4.0 International License. 


\section{Pendahuluan}

Perkembangan ilmu pengetahuan dan teknologi telah membawa perubahan dihampir semua aspek kehidupan manusia, termasuk dalam pendidikan formal. Keberhasilan pencapaian kompetensi suatu mata pelajaran bergantung kepada beberapa aspek antara lain ialah siswa, guru, mata pelajaran, kurikulum, metode pengajaran, saran dan prasarana. Aspek yang mempengaruhi keberhasilan pencapaian kompetensi yaitu guru, sebab gurulah yang terlibat langsung dalam upaya mempengaruhi, membina dan mengembangkan kemampuan peserta didiknya agar menjadi cerdas, terampil, dan bermoral tinggi serta berjiwa sosial sehingga siswa mampu mandiri sebagai makhluk individu maupun sosial. Selain guru, aspek yang paling mempengaruhi keberhasilan pencapaian kompetensi yaitu cara atau metode guru dalam menyampaikan materi pembelajaran. Guru tidak hanya berperan sebagai pendidik, namun juga harus bisa menjadi teladan, pemberi motivasi, dan pengarah bagi perkembangan siswa (Susilo, 2018). Dengan demikian, tugas guru sebagai pendidik harus mampu menciptakan suasana pembelajaran yang menyenangkan dan mampu meberikan motivasi belajar yang baik bagi siswa. Selain itu, salah satu tugas penting bagi guru adalah memberikan kemudahan bagi siswa dalam proses belajar mengajar serta mampu merancang perangkat pembelajaran dengan baik sehingga siswa dapat mengikuti proses belajar mengajar dengan penuh semangat (Hayati et al., 2017).

Penggunaan teknologi informasi dan komuikasi dewasa ini menjadi sebuah kebutuhan pokok dalam kehidupan yang tidak terbantahkan lagi. Pengaruh teknologi hari ini sudah merasuki disetiap sendi kehidupan manusia dalam berbagai hal apapun. Hal ini dipengaruhi karena teknologi mampu mempemudah kerja manusia. Termasuk dalam dunia pendidikan, pembelajaran yang beorientasi terhadap penggunaan teknologi mampu mengubah bentuk fiosofi pembelajaran danri pembelajaran berpusat pada guru (teacher centered) kepada pembelajaran berpusat kepada siswa (student centered) (Rinaldi et al., 2017). Oleh sebab itu, penggunaan teknologi untuk pembelajaran mampu memberikan proses belajar yang efektif dan efisien kepada siswa (Kristanto et al., 2017).

Dalam proses belajar, salah satu perangkat pembelajaran yang menjadi bagian tidak terpisahkan yang harus mampu dipilih dan digunakan serta dimanfaatkan oleh guru ialah media pembelajaran. Media pembelajarna mempunyai peranan yang sangat penting karena kehadiran media di dalam proses belajar mengajar akan mampu mempermudah siswa dalam menangkap konsep dasar dan ilmu pengetahuan dari sebuah materi ajar. Manfaat lain dari media pembelajaran adalah bahwa media akan mampu meningkatkan motivasi belajar siswa karena kehadiranya memberikan suatu hal yang mampu menarik perhatian siswa (Asmara, 2015) (Ainina, 2014) (Milosevic, 2017). Oleh sebab itu, penting bagi guru untuk memiliki kemampuan memilih, mengembangkan dan menerapkan media pembelajaran karena media pembelajaran memiliki peranan yang sangat penting bagi kesuksesan pembelajaran.

Media pembelajaran yang digunakan dalam penelitian ini adalah media pembelajaran berbasiskan audio visual yang memiliki peranan yang sangat penting bagi pembelajaran (Hasan, 2017). Salah satu pertimbangan menggunakan media audio visual ini adalah karena media ini dapat melatih konsentrasi dan focus siswa pada materi yang sedang diajarkan. Penayangan video sebagai salah satu contohnya selain menarik perhatian siswa, focus perhatian siswa akan terpusat karena detik demi detik para siswa tidak akan pernah rela untuk melewatkanya (Ode, 2014). Penayangan video pembelajaran ini juga mampu menghadirkan pengalaman nyata karena media audio visual dapat menampilkan relitas dari materi sehingga siswa terdorong untuk melakukan aktivitasnya sendiri (Fujiyanto et al., 2016). Untuk itu, pemanfaatan media 
audio visual ini juga tidak hanya dapat digunakan atau dimanfaatka oleh guru sebagai media pembelajaran saja, namun demikian media ini akan mampu emnumbuhkan kreatifitas siswa melalui kegiatan membuat video documenter sendiri yang selanjutnya dapat digunakan di dalam kelas dalam proses belajar mengajar (Laaser \& Toloza, 2017).

Penggunaan materi yang terdapat pada media audio visual umumnya memiliki durasi 7 sampai denga 10 menit akan mampu merangsang aktifitas dan merangsang pengembangan kemampuan siswa dalam merekonstruksi pengetahuan awal dengan pengetahuan yang didapat saat pembelajaran berlangsung (Pavlovich \& Marina, 2015).

Beberapa studi menggunakan media audio visual dilakukan oleh para peneliti. Studi oleh Mirvan (2013), Woottipong (2014) dan Sarani, Behtash dan Arani (2014) menyoroti bahwa persepsi siswa dalam menggunakan media video adalah positif karena dengan menggunakan media video, pemahaman mendengarkan mereka menjadi lebih baik dan mereka lebih tertarik untuk mempelajari keterampilan dan bahasa. Selanjutnya penelitian yang dilakukan oleh Eggiet \& Erviana (2018), Saragih (2015) memberikan kesimpulan bahwa media audio visual mampu mencapai komponen belajar dengan maksimal, menciptakan suasana atau kondisi belajar yang baik, serta mampu mendorong kreatifitas guru dalam membuat media pembelajaran. Sementara bagi pembelajaran BIPA, video pembacaan cerpen yang bermuatan budaya nasional Indonesia sekaligus memperkenalkan keragaman kebudayaan yang dimiliki oleh Indonesia kepada pemelajar BIPA (Alfayanti et al., 2017).

\section{Metode Penelitian}

Penelitian ini menggunakan metode eksperimen semu (Quasi Experiment). Sugiyono (2013: 114) menjelaskan bahwa "Metode eksperimen semu (Quasi Experiment) mempunyai kelompok kontrol, tetapi tidak dapat berfungsi sepenuhnya untuk mengontrol variabel-variabel luar yang mempengaruhi pelaksanaan eksperimen". Desain penelitian yang digunakan dalam penelitian ini adalah Nonequivalent Control Group Design. Menurut Sugiyono (2013: 116) menjelaskan bahwa "Dalam desain Nonequivalent Control Group Design terdapat kelompok eksperimen dan kelompok kontrol yang tidak dipilih secara random serta dilakukannya pretest dan posttest pada masing-masing kelompok".

Berdasarkan desain penelitian di atas, prosedur penelitian ini dibagi menjadi tiga tahapan yaitu sebagai berikut:

1. Tahap Persiapan

Pada tahap persiapan ini segala sesuatu yang dibutuhkan dalam penelitian disiapkan. Persiapan dalam penelitian ini diantaranya menyusun perangkat pembelajaran dan instrumen penelitian, kemudian perangkat pembelajaran dan instrumen penelitian tersebut di revisi oleh dosen pembimbing. Selanjutnya peneliti juga menentukan populasi penelitian yaitu siswa kelas V SD Negeri Leuwikidang I, menentukan secara acak kelas sampel, yaitu kelas eksperimen dan kelas kontrol, kemudian menentukan kelas uji coba diluar kelas sampel. Setelah itu instrumen uji coba diuji cobakan pada kelas uji coba yaitu kelas VI SD Negeri Leuwikidang I, hal tersebut dilakukan untuk mengetahui validitas dan reliabilitasnya.

2. Tahap Pelaksanaan Eksperimen

Pada tahap ini kegiatan yang dilakukan memberikan Pretest untuk mengetahui kemapuan awal pemahaman pada mata pelajaran Bahasa Indonesia yang diberikan pada masing-masing kelas yaitu kelas eksperimen dan kelas kontrol. Selanjutnya kegiatan yang dilakukan adalah melakukan pembelajaran dengan memberikan perlakukan (treatment) pada subjek penelitian, perlakukan yang diberikan pada kelas eksperimen atau kelas V B adalah pembelajaran dengan menggunakan media audio visual danpembelajaran pada kelas 
kontrol atau kelas V A adalah pembelajaran tanpa menggunakan media audio visual. Setelah perlakuan (treatment) diberikan kepada kelas eksperimen, selanjutnya melakukan kegiatan Posttest pada semua siswa kelas eksperimen dan siswa kelas kontrol. Hal tersebut bertujuan untuk mengetahui pengaruh perlakuan pembelajaran yang menggunakan media audio visual dengan pembelajaran tanpa menggunakan media audio visual, terhadap hasil belajar siswa pada mata pelajaran Bahasa Indonesia dengan materi daur air.

3. Tahap Pengolahan Data dan Penulisan Laporan

Pada tahap ini yaitu setelah data terkumpul maka peneliti melakukan pengolahan data, analisis data dengan membandingkan hasil antara kelompok kontrol dengan kelompok eksperimen, serta menarik kesimpulan sesuai dengan tujuan penelitian.

4. Instrument yang digunakan dalam penelitian ini adalah Lembar Kerja Proses (LKP). Pelaksanaan tes dilaksanakan berdasarkan prosedur pembelajaran Bahasa Indonesia yakni pra pembelajaran, pembelajaran, dan pasca pembelajara

5. Analisis data yang digunakan dalam penelitian ini adalah dengan menggunakan teknik analisis data statistic inferensial.

\section{Hasil dan Pembahasan}

Dalam melaksanakan penelitian dihasilkan data kualitatif dan data kuantitatif. Data kualitatif diperoleh melalui lembar observasi guru dan aktivitas siswa yang diberikan kepada teman sejawat yang menjadi observer pada saat pembelajaran berlangsung. Sementara itu data kuantitatif diperoleh melalui pretes maupun postes hasil belajar Bahasa Indonesia siswa.

1. Uji Normalitas

Uji normalitas digunakan untuk mengetahui normal atau tidaknya data yang menjadi syarat untuk menentukan jenis statistik yang akan dilakukan dalam analisis selanjutnya. Untuk mempermudah perhitungan uji normalitas dalam penelitian ini dibantu dengan software SPSS versi20 dengan menggunakan uji Shapiro-Wilk. Adapun hasil uji normalitas postes hasil belajar Bahasa Indonesia dapat dilihat pada tabel berikut:

Tabel 1

\begin{tabular}{lcccc}
\multicolumn{5}{c}{ Hasil Uji Normalitas Data Postes } \\
\cline { 3 - 5 } & \multirow{3}{*}{ Kelas } & \multicolumn{3}{c}{ Shapiro-Wilk } \\
\cline { 2 - 5 } & Statistic & Df & Sig. \\
\hline Kont Test & Kontrol &, 928 & 20 &, 139 \\
\hline Hasil & Eksperimen &, 933 & 20 &, 177 \\
Belajar & & & & \\
Bahasa & & & & \\
Indonesia & & & & \\
\hline
\end{tabular}

Berdasarkan hasil pengukuran tabel di atas, bahwa postes hasil belajar Bahasa Indonesia kelas eksperimen mempunyai tarafsignifikansi sebesar 0, 177 atau lebih dari 0,05, maka dapat dikatakan data tersebut berdistribusi normal. Sedangkan untuk hasil postes hasil belajar Bahasa Indonesia kelas kontrol mempunyai taraf signifikansi sebesar 0,139 atau lebih dari 0,05 , maka dinyatakan bahwa data tesebut berdistribusi normal. Nilai signifikansi kedua kelompok tersebut lebih besar dari 0,05 maka H0 diterima. Dari hasil uji normalitas tersebut dapat disimpulkan bahwa data postes kelas eksperimen dan kelas kontrol yang diperoleh berdistribusi normal. Maka selanjutnya akan digunakan uji homogenitas.

2. Uji Homogenitas

Data hasil postes dari kelas eksperimen dan kelas kontrol tersebut berdistribusi normal, maka analisis data dilanjutkan dengan uji homogenitas. Uji homogenitas dilakukan 
untuk mengetahui apakah varian kedua kelas tersebut sama (homogen) atau berbeda. Hasil uji homogenitas dapat dilihat dari output test homogenity of variance. Adapun hasil uji homogenitas kelas eksperimen dan kelas kontrol dapat dilihat pada tabel sebagai berikut:

Tabel 2

Hasil Uji Homogenitas Data Postes

\begin{tabular}{|c|c|c|c|c|c|}
\hline & & $\begin{array}{l}\text { Levene } \\
\text { Statistic }\end{array}$ & df1 & df2 & Sig. \\
\hline \multirow{4}{*}{$\begin{array}{l}\text { Pos Test } \\
\text { Hasil } \\
\text { Belajar } \\
\text { Bahasa } \\
\text { Indonesia }\end{array}$} & $\begin{array}{l}\text { Based on } \\
\text { Mean }\end{array}$ & ,034 & 1 & 38 & ,854 \\
\hline & $\begin{array}{l}\text { Based on } \\
\text { Median }\end{array}$ & ,019 & 1 & 38 & ,891 \\
\hline & $\begin{array}{l}\text { Based on } \\
\text { Median } \\
\text { and with } \\
\text { adjusted } \\
\text { df }\end{array}$ & ,019 & 1 & 37,482 & ,891 \\
\hline & $\begin{array}{l}\text { Based on } \\
\text { trimmed } \\
\text { mean }\end{array}$ & ,036 & 1 & 38 &, 850 \\
\hline
\end{tabular}

Berdasarkan hasil perhitungan Tabel di atas diperoleh nilai signifikansi postes hasil belajar Bahasa Indonesia kelas eksperimen dan kelas kontrol adalah 0,854. Nilai signifikansi kedua kelompok tersebut lebih besar dari 0,05 maka H0 diterima, artinya sampel kedua kelompok mempunyai varian yang sama (homogen). Jadi dapat disimpulkan bahwa kedua sampel tersebut memiliki varian yang homogen atau data berasal dari populasi dengan varian yang sama.

3. Uji t Dua Sampel Independen (Independent Sample Test)

Data postes diperoleh berdistribusi normal dan homogen maka analisis untuk menguji hipotesis digunakan uji $t$ Independent Sample Test. Uji $t$ Independent Sample Test dilakukan untuk mengetahui perbedaan rata-rata skor hasil belajar Bahasa Indonesia siswa antara kelas eksperimen dan kelas kontrol. Dimana kelas eksperimen diberikan perlakuan menggunakan media Audio Visual sedangkan kelas kontrol tanpa menggunakan media Audio Visual.

Untuk mempermudah perhitungan Uji t Independent Sample Test, maka penelitian ini menggunakan software SPSS Statistic 20. Dengan kriteria pengujiannya adalah jika nilai signifikansi kurang dari 0,05 maka $\mathrm{H} 0$ ditolak, sedangkan jika nilai signifikansi lebih dari 0,05 maka H0 diterima. Hasil uji $\mathrm{t}$ dua sampel independen posteskelas eksperimen dan kontrol dipaparkan pada tabel berikut:

Tabel 3

Hasil (Uji t) Data postes

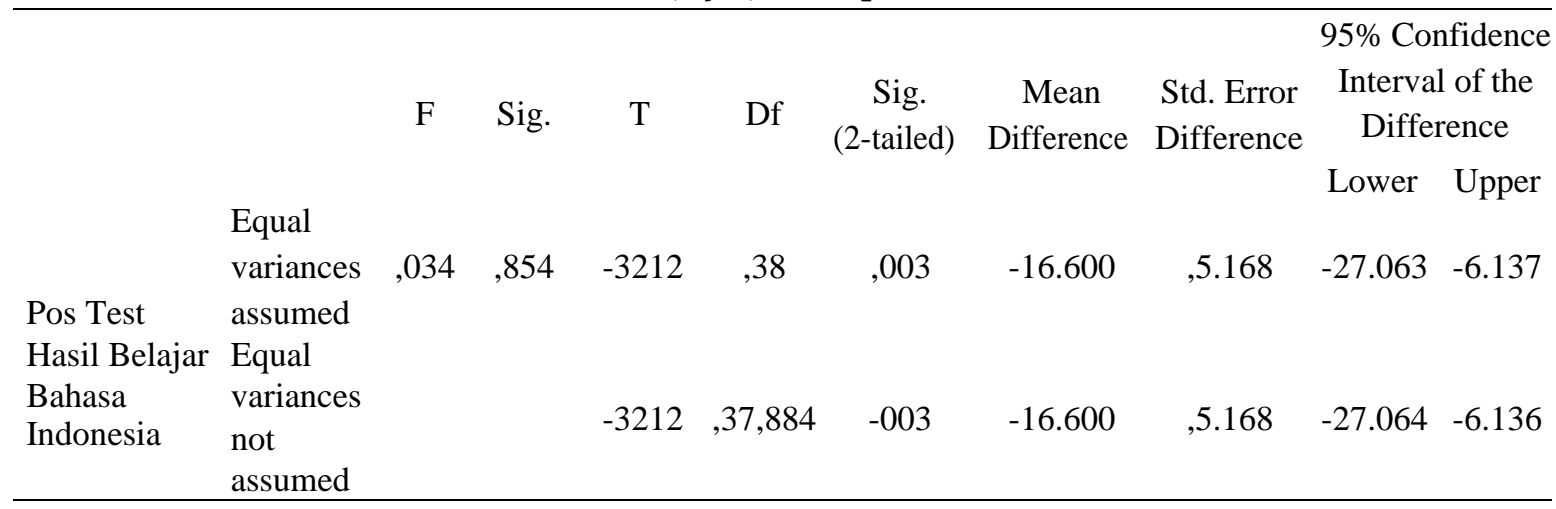


Berdasarkan tabel di atas, hasil analisis uji t menunjukkan bahwa nilai signifikansi (2-tailed) sebesar 0,003.Nilai signifikansi tersebut kurang dari 0,05, maka dapat dinyatakan bahwa Ho ditolak, yang artinya ada perbedaan yang signifikan hasil postes hasil belajar Bahasa Indonesia kelas eksperimen dengan kelas kontrol. Dengan demikian, dapat disimpulkan bahwa terdapat perbedaan yang signifikan hasil belajar Bahasa Indonesia siswa antara siswa yang memperoleh pembelajaran dengan menggunakan media Audio Visual dantanpa menggunakan media Audio Visual.

Perbedaan tersebut didasarkan pada hasil postes masingmasing kedua kelas tersebut. Kelas eksperimen mengalami peningkatan yang lebih besar dibandingkan dengan kelas kontrol. Sehingga dapat dikatakan pembelajaran dengan menggunakan media Audio Visual lebih baik dibandingkan dengan tanpa menggunakan media Audio Visual.

Hasil penelitian menunjukan adanya pengaruh dari penggunaan media audio visual terhadap hasil belajar bahasa Indonesia pada siswa kelas V sekolah dasar. Pembelajaran dengan menggunakan media audio visual memberikan dampak yang sangat signifikan bagi siswa. Dampak yang sangat terasa adalah berkenaan dengan motivasi belajar siswa. Penggunaan media mampu membangkitkan motivasi belajar siswa untuk senantisa meningkatkan keterampilan berbahasa siswa (Supriatini, 2017). (Proses pelaksanaan pembelajaran berjalan sangat efektif dan efisien karena selama proses pembelajaran berlangsung fokus perhatian siswa sangat terjaga (Goretti et al., 2014) (Musfikon, 2012). Rasa antusias siswa dapat tergambarankan dalam proses pembelajaran sebagian besar siswa dapat berinteraksi dan berkomunikasi secara aktif dengan guru. Walau ada beberapa siswa yang masih terlihat kurang antusian di awal-awal pembelajaran, namun seiring dengan proses pembelajaran akhirnya guru mampu mengatasi dan mengkondisikan kelas sehingga sleuruh siswa dapat terlibat aktif dalam pembelajaran. Hal ini membuktikan bahwa teknologi memiliki peranan penting dalam proses pembelajaran apabila digunakan dengan bijak oleh para guru .

Berdasarkan hasil penelitian yang dilaksanakan, hal ini sejalan dengan penelitian yang dilaksanakan oleh peneliti, selanjutnya hasil dari penelitian lain juga dapat disimpulkan bahwa penggunaan media pembelajaran berbasis audio visual pada mata pelajaran konstruksi bangunan sub materi batu bata memberikan pengaruh terhadap hasil belajar. Hal ini dibuktikan Berdasarkan nilai hasil belajar yang diperoleh, pada kelas eksperimen rata-rata nilai pre-test sebesar 55,79 dan terjadi peningkatan yang signifikan di hasil post-test dimana pada kelas eskperimen mendapatkan nilai rata-rata sebesar 89,54. Sedangkan untuk kelas kontrol rata-rata nilai pre-test yang diperoleh sebesar 62,39 dan pada saat post-test memperoleh nilai rata-rata sebesar 82,61 (Rinaldi et al., 2017). Berikutnya hasil penelitian dari Ekowati el al (2015) menyatakan bahwa berdasarkan hasil analisis data memberikan kesimpulan bahwa media audio visual telah memenuhi kelayakan dan dapat digunakan sebagai media pembelajaran karena dapat meningkatkan hasil belajar siswa

\section{Kesimpulan}

Berdasarkan pemaparan pembahasan tersebut, dapat disimpulkan bahwa media lebih efektif dalam meningkatkan hasil belajar siswa jika dibandingkan tanpa menggunakan media Audio Visual. Media dapat mengaktifkan seluruh siswa selama proses pembelajaran dan memberikan kesempatan untuk bekerjasama antar siswa yang mempunyai kemampuan heterogen. 


\section{Daftar Pustaka}

Ainina, I. A. (2014). Pemanfaatan Media Audio Visual Sebagai Sumber Pembelajaran Sejarah. Indonesian Journal of History Education, 3(1).

Alfayanti, L., Suwandi, S., \& Winarni, R. (2017). Penggunaan Media Audio Visual Video Pembacaan Cerpen Bermuatan Budaya Nasional Indonesia untuk Kompetensi Menelaah Karya Satra Bagi Pemelajar BIPA. Proceedings of Education and Language International Conference, 1(1), 624-629. http://garuda.ristekdikti.go.id/documents/detail/497277

Asmara, A. P. (2015). Pengembangan Media Pembelajaran Berbasis Audio Visual Tentang $\begin{array}{lllll}\text { Pembuatan Koloid. Jurnal Ilmiah Didaktika, } 15(2), & 156 .\end{array}$ https://doi.org/10.22373/jid.v15i2.578

Eggiet, Erviana Vera Yuli (2018) Penggunaan Media Audio Visual Dalam Pembelajaran Bahasa Indonesia Di Kelas V Sd Muhammadiyah Domban 2. Jurnal Fundamental Pendidikan Dasar FUNDADIKDAS Vol. 1 No. 1 Edisi Maret 2018. http://journal2.uad.ac.id/index.php/fundadikdas/article/view/963/pdf

Ekowati N, Mustaji, \& Subroto W T. (2015) Pengembangan Media Audio Visual Terhadap Perkembangan Teknologi Produksi, Komunikasi, dan Transportasi Untuk Meningkatkan Hasil Belajar Mata Pelajaran IPS Bagi Siswa Kelas IV Sekolah Dasar. Jurnal Riview Pendidikan Dasar: Jurnal Kajian Pendidikan dan Hasil Penelitian Vol 1 No 1 Tahun 2015. DOI: $10.26740 /$ jrpd.v1n1.p44-50

Fujiyanto, A., Jayadinata, A. K., \& Kurnia, D. (2016). Penggunaan Media Audio Visual Untuk Meningkatkan Hasil Belajar Siswa Pada Materi Hubungan Antarmakhluk Hidup. Penggunaan Media Audio Visual Untuk Meningkatkan Hasil Belajar Siswa Pada Materi Hubungan Antarmakhluk Hidup, 1(1), 841-850. https://doi.org/10.23819/pi.v1i1.3576

Goretti, M., Mudjiman, H., \& Haryanto, S. (2014). Penerapan Media Audio Visual dalam Pembelajaran Bahasa Inggris. Jurnal Teknologi Pendidikan Dan Pembelajaran, 2(1), 79-92.

Hasan, H. (2017). Penggunaan Media Audio Visual Terhadap Ketuntasanbelajar Ips Materi Perkembangan Teknologi Produksi, Komunikasi, Dan Transportasi Pada Siswa Kelas Iv Sd Negeri 20 Banda Aceh. Jurnal Pesona Dasar, 3(4), 22-33.

Hayati, N., Ahmad, M. Y., \& Harianto, F. (2017). Hubungan Penggunaan Media Pembelajaran Audio Visual dengan Minat Peserta Didik pada Pembelajaran Pendidikan Agama Islam di SMAN 1 Bangkinang Kota. Jurnal Al-Hikmah, 14(2), 160-180.

Kristanto, A., Mustaji, M., \& Mariono, A. (2017). The Development of Instructional Materials E-Learning Based On Blended Learning. International Education Studies, 10(7), 10. https://doi.org/10.5539/ies.v10n7p10

Laaser, W., \& Toloza, E. A. (2017). The changing role of the educational video in higher distance education. International Review of Research in Open and Distance Learning, 18(2), 264-276. https://doi.org/10.19173/irrodl.v18i2.3067

Milosevic, D. (2017). Using video materials in English for technical sciences: a case study. New Developments in ESP Teaching and Learning Research, 2017, 15-30. https://doi.org/10.14705/rpnet.2017.cssw2017.743

Mirvan, X. (2013). The advantages of using films to enhance student's reading skills in the EFL classroom. Journal of Education and Practice, 4(13), 62-66.

Musfiqon. (2012). Pengembangan Media \& Sumber Pembelajaran. Jakarta. Prestasi Pustaka Raya. 
Ode, E. O. (2014). Impact of Audio-Visual (AVs) Resources on Teaching and Learning in Some Selected Private Secondary Schools in Makurdi. International Journal of Research in Humanities, Arts and Literature (IMPACT: IJRHAL), 2(5), 195-202. http:/ /www.impactjournals.us/journals.php?id=11\&jtype $=2 \&$ page $=9$

Pavlovich, A. E., \& Marina, V. (2015). Use of audiovisual texts in university education process. Mediterranean Journal of Social Sciences, 6(1S2), 31-35. https://doi.org/10.5901/mjss.2015.v6n1s2p31

Rinaldi, A. A., Daryati, D., \& Arthur, R. (2017). Penggunaan Media Pembelajaran Berbasis Audio Visual untuk Mata Pelajaran Konstruksi Bangunan. Jurnal PenSil, 6(1), 7. https://doi.org/10.21009/jpensil.v6i1.7231

Saragih M. S. (2015) Penggunaan Media Audio Visual Untuk Meningkatkan Hasil Belajar Menyimak Dalam Pembelajaran Bahasa Indonesia. Jurnal Pendidikan dan Pembelajaran $\begin{array}{lllllll}\text { Khatulistiwa } & \text { Vol } & 4 & \text { No } & 2 & \text { Tahun } & 2015 .\end{array}$ http://jurnal.untan.ac.id/index.php/jpdpb/article/view/9127

Sarani , A. Behtash, E. Z., \& Arani, S. N. (2014). The Effect of Video-Based Tasks in Listening Comprehension of Iranian Pre-intermediate EFL Learners. Gist Education and Learning Research Journal, 29-47.

Supriatini, S. (2017). Penerapan Media Audio Visual Dalam Meningkatkan Keterampilan Menulis Puisi Siswa Kelas Viii Smp Negeri 13 Palembang. Jurnal Bindo Sastra, 1(1), 45. https://doi.org/10.32502/jbs.v1i1.667

Susilo, S. V. (2018). Refleksi Nilai-Nilai Pendidikan Ki Hadjar Dewantara Dalam Upaya Upaya Mengembalikan Jati Diri Pendidikan Indonesia. Cakrawala Pendas, 4(1), 33-41. https://doi.org/http://dx.doi.org/10.31949/jcp.v4i1.710

Woottipong, K. (2014). Effect of Using Video Materials in the Teaching of Listening Skills for University Students. International Journal of Linguistics, 6(4), 200-212. https://doi.org/10.5296/ijl.v6i4.5870 